\title{
Jean Piaget's Genetic Epistemology as a Theory of Knowledge Based on Epigenesis
}

\author{
By Zelia Ramozzi-Chiarottino*
}

\begin{abstract}
This article aims to highlight Jean Piaget's theory of knowledge and situate it in this context since its beginnings in Ancient Greece where, in Plato, we already find this seminal idea: knowledge is acquired in successive and upward moments (dialektikê), starting from an opinion on the sensible world (doxa) towards the épistêmê of the intelligible world, the world of Ideas or concepts. Piaget's Theory of Knowledge, we believe, was determined by four moments: 1) his research as a malacologist under the guidance of Godet and Raymond, 2) the acquaintance with Kant's philosophy at age of 21,3) his internship at the Binet/Simon laboratory, 4) his studies on the Limnaea Stagnalis. His core idea: it is possible for human beings to attain the necessary and universal knowledge due to the exchange processes of their organisms with the environment, which give rise to the epigenetic ontogenesis of their specific organic mental structures, framed for the specific act of knowing. Epigenetic ontogenesis begins with the infans first actions in the world, from the very moment of birth. Around two years of age, these actions will be represented and organized in groups linked to empirical experience, until the brain be able to perform the operations of the Abelian Group. The physiological development ends here, and the logico-mathematical knowledge becomes possible.
\end{abstract}

\section{Introduction}

The title of this article may be a surprise to many, since Jean Piaget has always been recognized as a gifted psychologist (but not a biologist). In reality, however, Piaget was a biologist/zoologist who dedicated himself to epistemology. Apart from his interest in biology/zoology, Piaget has always been interested in the education of human beings, as well as with the construction of Genetic Epistemology. Piaget expressed his interest in education at the beginning of his career and subsequently dedicated to it about 400 out of the 20,000 pages he wrote on epigenetic/ontogenetic evolution of rationality (which makes possible scientific knowledge), through which Piaget aimed to create a tertium between Darwin and Lamarck. ${ }^{1}$

In this work we aim to demonstrate that Jean Piaget achieved his youth dream (1918) by creating a Theory of Knowledge based on Biology and, in

"Professor, São Paulo University, Brazil.

1. Z. Ramozzi-Chiarottino, G. Franck-Cunha, J.-J. Freire and A. A. Ferraz, Jean Piaget's Unrecogized Epigenetic Ontogenesis of the Logical-Mathematical Thought (Athens: Atiner's Conference Paper Series, 2017). 
addition, show that it is inserted in the History of Philosophy which arose in Ancient Greece and has reached our days. A classical Theory of Knowledge and at the same time an absolutely contemporary one insofar as Biology is "par excellence" the theme of Knowledge in our century.

\section{Methodology}

The Method of this article consisted in: a) identifying a gnosiology that seeks the origin and nature of the human faculty of knowing in Jean Piaget's work; and b) positioning it in its due place in Western Philosophy's history.

\section{Prolegomena}

Let us begin this article by returning to a classic question posed at the dawn of Philosophy: "Is it possible for humans to attain Knowledge (épistêmê)? If so, does Knowledge come to us through the senses in contact with experience, or is it the prerogative of pure Reason?"

The philosophic thinking of Parmenides of Elea and Heraclitus of Ephesus are the icons of the answer to that question in the History of Ideas. The former asserted: "Being Is, no-Being does not exist", therefore "Being" has always existed; it will be eternal and not subject to transformation, for if it had started on a day or should come to end on day or should undergo changes, it could only be transformed into "Non-Being", but "Non-Being" does not exist. Heraclitus, for believing only in the information coming from the senses, stated: "Nothing ever is, but everything is becoming." The opposition between knowledge that is pure reason, or pure logic (before logic was first created by Aristotle), and the knowledge that comes to us through the senses is very clear, as Heraclitus put it: No man ever steps in the same river twice. The opposition between rational enquiry and the immediate impressions of senses is clear, a dilemma that persists even today, albeit with different wording. ${ }^{2}$

Parmenides and Heraclitus thought has survived only, as is known, in their Fragments, with all the difficulties of their reconstruction. We only have a few fragments of Parmenides, and it was precisely the interest in his logic which led us to the study of Philosophy at the age of 16; decades later I was given a great gift - a versions of Parmenides Fragments (1997). ${ }^{3}$ Here are some examples of the reflections of Parmenides: B3 - (...) "For thinking and being are the same." (Descartes reached the same conclusion 2000 years later, as the unquestionable knowledge of Reason: "Je pense, je suis"). Let us continue with Parmenides in fragment B4 -

2. G. G. Granger, La Vérification (Paris, Odile Jacob, 1992).

3. J. Trindade dos Santos, Fragmentos do Poema de Parmênides (Lisboa: Gulbekian, 1997). 
"Look as the things afar that by the thinking become present" (words that will be repeated by Immanuel Kant when explaining imagination as a priori form of sensibility) - (...) B6 - It is absolutely necessary that the Being, speaking and thinking exist, nothingness does'not existe this is what I bid you to ponder. Keep a distance from this way of inquiry and also from the one upon which mortals, who know nothing, wander (...) and in whose eyes being and non-being are the same (...)

Plato overcame this dichotomy by showing us that knowledge is achieved through Dialogue, whose upward dialectic movement derives from the sensitive multiplicity from our empirical experience toward the intelligible world, of the Ideas or concepts as intelligible unities.

Curiously and unexpectedly, in Plato's Dialogues ${ }^{4}$ we can find Piaget's seminal idea: knowledge is acquired in successive and upward moments (dialektikê), starting from an opinion about the sensible world (doxa) towards the épistêmê of the Ideas World. The visible world is a matter of opinion and it is nothing more than an image (éikôn) of the intelligible world, an imitation of eternal essences. Plato in his mythical and poetic language described a reality demonstrated two thousand or so years later by Jean Piaget. He states that the human faculty of knowledge evolves in a dialectical process, passing from the simple ability to act in the sensitive multiplicity of the empirical world to achieve scientific knowledge made up of concepts as intelligible unities. That accomplishment will be possible only after dialectical evolution of Reason itself as Plato describes. According to Piaget knowledge and Reason evolve indefinitely. Some will say that Plato's Eternal Truths, Essences or Ideas, as indicated by the expression itself, are immutable. Nevertheless, Plato's Dialogues allow the understanding of dialectical inquire will never completely attain the essences. The dream of attaining absolute knowledge always eludes us, as Ideas will never show their real splendor to anyone... Thus, in mythical language, Plato discloses to us his conception of knowledge: for him too, knowledge will evolve indefinitely.

On the other hand, Dialectics overcomes the dichotomy between the senses and Reason, even if all knowledge begins with experience an starter of reminiscences of the World of Ideas, the place and time where the souls lived before their reincarnation. Socrates states in Menon: "ah! How I miss the world of Ideas!" For he had contemplated them better than anyone else, and precisely for that reason his soul once incarnated in this World chose to be a philosopher. Thus, only through Reason can one reach the intelligible world and the épistêmê, as already mentioned. Nevertheless, this upward movement will emerge in the epigenetic Piagetian ontogenesis of mental structures towards the acquisition of logical - mathematical knowledge, which can always evolve without ever reaching an end.

Many centuries later...

4. Plato, Dialogues (trans.) Émile Chambry (Paris: Garnier- Flamarion, 1969). 
For Descartes, the founder of modern Rationalism, Je pense, je suis is the foundation of his entire philosophy, as the first unquestionable knowledge attained by Reason, which never passed through the senses. ${ }^{5}$ [It is well known that he removed the word "therefore", "donc", so that his statement would not be confused with the conclusion of a medieval syllogism.] This statement stems from "the enquiry of mind (esprit)" through which the philosopher attains the truth without relying on metaphysics or religion. In his view the senses perceives the sensible world, but this information only becomes Knowledge after "being processed" by esprits animaux, by the brain (in his original texts that is exactly the word he uses: cerebro, brain). Thought and res extensa or body, are for him "two modes of the same substance", (cogitatio $\mathcal{E}$ extension sumi etiam possunt pro modis substantiae); ${ }^{6}$ however, both concepts had been understood in the philosophical debate since the $18^{\text {th }}$ century such as "body" and "soul", a dualism that contradicts his own claims. On page 41 of the same volume VIII, one can read in a Descartes text, translated by us: "everything we perceive through our senses concerns the strict union the soul keeps with the body". A careful reading of Descartes original texts in Latin and Old French displays the misunderstanding of a Cartesian dualism. Jean Piaget $^{7}$ thus writes: Some think that it was precisely the creation of Analytical Geometry that determined in Descartes' Philosophy the permanent issue of the relations between understanding and the res extensa, "both inseparable and fundamentally different concurrently". Piaget demonstrates the concurrent evolution of body and Reason, "both inseparable and fundamentally different," by explaining the epigenetic ontogenesis of mathematical logical thinking in his Genetic Epistemology.

Descartes was contradicted by David Hume's skepticism. The dichotomy initiated by Parmenides and Heraclitus reappears. In addition to placing sensitive experience as the only source of knowledge, Hume, the father of Modern Empiricism, deconstructs the logical link or the physical necessity of the causal relations accepted in his time.

Let us remember that Hume's statements are subsequent to the discoveries and inventions of Copernicus, Galileo, Kepler and Newton. Scientists were interested in explaining the physical world, but their metaphysical convictions loomed above everything and coincide with their discoveries. Kepler concludes his works with a prayer: "I give Thee thanks, O Lord, for letting me know a small part of the Universe Thou hast created."

Immanuel Kant, says Cassirer, came to disrupt this harmony by denying Metaphysics the place it occupied until then asking himself: "Is Metaphysics

5. C. Adam and P. Tannery, Oeuvres de Descartes (Paris: Vrin, 1969/1996), 30-32.

6. Ibid, 31.

7. J. Piaget, Sagesse et Illusions de la Philosophie (Paris, 1965b).

8. Apud W. Heisenberg, La Nature dans la Physique Contemporaine (Paris: Gallimard, 1962), 82-97. 
possible?" And within what limits? What was an indisputable foundation of truth until then becomes a disputable one and analyzed with critical arguments. According to Kant, this is about a revolution in the dominion of knowledge, as analogous to the Copernican revolution in Astronomy. Kant does not address himself the question whether knowledge is possible since Mathematics and Physics, for him, are already necessary and universal knowledge; nevertheless, he investigates how they are possible.

Cassirer states that with Kant Logics and dialectics are no longer a simple organon of the knowledge of reality, but also encompasses them in all their fullness and wholeness:

"Thus, the orbit of philosophical thought seemed to be complete for the first time after having achieved its goal, the identity between reality and Reason. "Such was the point he believed he had reached in "Hegel's Science of Logic" (Wissenchaft der Logik, 1812). What Hegel condemned in Kant's logic and the ones that preceded it was their inability to overcome the purely "formal" point of view, which made them adhere to mere abstraction and reflection. According to Hegel, paving this way does not enable us to leave the circle of subjectivism. It is necessary for the spirit to breathe life into the "skeleton" of logic, to give it nerves and "muscles". This is precisely what the dialectical method promises, and what only this method is able to deliver." ${ }^{\prime 9}$

\section{Jean Piaget's Theory of Knowledge}

Jean Piaget's Genetic Epistemology fulfilled Hegel's aspirations, as Cassirer understood them, and through a dialectical method, by explaining the epigenetic ontogenesis of specific organic mental structures for the act of knowing, for the first time in the history of ideas, breathed life in the skeleton of Logic giving it nerves and muscles, thus creating the Theory of Knowledge he envisioned since his youth. ${ }^{10}$

Piaget's Theory of Knowledge, in our view, can only be understood if we bear in mind the four moments of his life which determined it:

1) First, he started his career as a zoologist when he was still a youngster under the guidance of malacologist Paul Godet and then under the orientation of logician Arnold Reymond. Piaget states ${ }^{11}$ that studying under A. Reymond made it possible for him to understand the link of the

9. E. Cassirer, El Problema del Conocimiento, de la Muerte de Hegel a Nuestros Dias (Mexico, Buenos Aires: Fondo Del Cultura, 1948), 10-11.

10. G. Cellerier, Piaget (Paris: P.U.F., 1973), 6; Piaget, Recherche (Lausanne: La Concorde, 1918).

11. Piaget, "Les Modèles Abstraits sont-il Opposés aux Interprétations Psychophysiologiques dans l'Explication en Psychologie?" Revue Suisse de Psychologie pure et appliquée XIX, no. 1 (1960) : 59. 
biological forms to the logical structures in such a perspective that there was no more conflict between them, but instead a close union between organic forms and those of intelligence, i.e., the logical and mathematical thinking. Furthermore, upon studying biometrics Piaget arrives at the conclusion that a qualitative biology remains verbal and that the problem of forms and structures in biology need logical and mathematical models for a true explanation. Afterwards he will proceed to the University.

2) The acquaintance of Piaget with Immanuel Kant's Philosophy at age 21, and the idea of explaining it in the light of Biology as he tells us in an autobiographical text. ${ }^{12}$ Piaget states that he makes three discoveries that modify his naïve biologism: "the first discovery is that if we start with Le Dantec, on the duality of functions, named assimilation and imitation by him; whereas I would say assimilation and accommodation. Knowledge is not merely imitation as he believed in his empiricism, but, in fact, an assimilation to the structures of the subject and the organism. It was gently moving from Le Dantec on to an evolutionary Kantianism."

In transposing Kant's theory into Biology, Piaget will answer that Mathematics and Physics are attainable for humans due to the epigenetic ontogenesis of the logical mathematical thinking. This ontogenesis, we shall see, consists of a constant process of assimilation and accommodation of the organism and is built in the event of disturbances and requests from the environment, to which it adapts and then becomes unbalanced again due to the capacity of the brain to perceive new stimuli and so expand its world. Initially, these stimuli are present in the environment only, but they are also within the scope of abstract and formal representations of this empirical world.

The explanation of this ontogenesis will constitute his Theory of Knowledge based on Biology, envisioned since Piaget's early years as mentioned previously.

Kant tells us that "all knowledge begins with experience, but it does not derive from $i t, " 13$ because, according to him, experience is structured and explained by the categories of Understanding (Verstand) that correspond to those a priori of Pure Reason (Vernunft) and thanks to which, even it is made possible. Understanding connects directly with experience, and Pure Reason is constituted by mental units of the multiple parts, the concepts as formal possibilities of all attainable knowledge. Thus, according to Kant, knowledge would not exist without a priori categories of Reason and the imaginative capacity of humans, (Einbildungskraft) ${ }^{14}$ responsible for the "necessary unity of a phenomena-based synthesis" in consciousness. In his view, knowledge is an elaboration of an active thought of the matter of intuition, according to a priori principles, i. e., the application of these principles to

12. Ibid, 58-59.

13. I. Kant, Critique de la Raison Pure (Paris: PUF, 1781/1950), 31.

14. R. Eisler, Kant-Lexikon (Paris: Èditions Gallimard, 1994), 524. 
sensitive data, which results in their subordination to the forms of consciousness "which knows", that is, incorporating the result of all intuition and, let us say, of perception, in a unified and systematic set - knowledge. "The requirement that proves itself to be the proper principle of Reason in its logical use is to find, for the conditioned knowledge of understanding, the unconditioned that must lead to unity."15 That would be the condition of all attainable knowledge.

For Piaget, knowledge begins with an action which has is nevertheless a consequence of an endogenous process, whose primary source is the brain, and therefore it does not derive from it. For Kant, Reason is abstract, whereas in Piaget's view, it is organic.

Piaget also believes in a priori as a condition of all attainable knowledge, but not previously chronologically given; in fact, fully constructed step by step. His conviction that every moment of epigenetic evolution is necessary for the construction of the one that succeeds it, that is, every moment is a priori condition of the next moment. According to Piaget the framing of the epistemic subject, dialectically built (organism and environment) is richer than Kant's epistemic subject, since the very beginning. ${ }^{16}$

3) The third decisive moment in Piaget's life for the construction of his Theory of Knowledge was his internship at Binet and Simon's Laboratory. Then and there he discovered a logic underlying children's actions: inclusion, addition, multiplication of classes, fitting of transitive asymmetric relations etc., whose model was Couturat's classical logic he had studied at a very young age. This logic, he realizes, foreshadowed a Logic of Classes and Relations and it was not a matter of abstractions or chimeras, "I saw them being constructed."17 A second fundamental finding was that the logic underlying a child's behavior evolves. Would this logical enrichment come from experience or would it just be a development of inherited possibilities? Or both?

At the beginning of his internship, Piaget believed that language unveiled the very logic of thought. However, he later observed that this logic is present -even if not in evident way- in human actions, organizing them and making discoveries possible. Piaget then had the idea of studying children's behavior from the day of their birth. So he started to observe his first daughter Jacqueline born 1925, and then carried on with the other two children: Luciènne and Laurent. For more than 10 years of observation he collected data to make his hypotheses more precise. Then he realized that in all kinds of behavior, both in

15. Ibid, 888.

16. Piaget, Sagesse et Illusions de la Philosophie, 1965b, 82.

17. Piaget, "Les Modèles Abstraits sont-il Opposés aux Interprétations Psychophysiologiques dans l'Explication en Psychologie?" 1960, 60. 
the one that seeks an immediate goal and as in any type of game, children's actions are not structured randomly. They obey true logical systems that determine their behavior without their being aware of them, similarly there are laws ruling our endocrine system without our being aware of them at the level of consciousness.

4) The fourth decisive moment for the construction of Piaget's Theory of Knowledge was the research conducted with the Limnaea Stagnalis, from 1927 to 1965, (80,000 individuals), published in the 1929 and 1965a Reports. So that research took place in parallel with his observations of his children's behavior. Why did this work that referred to phylogenesis occur to him at the moment he was busy with ontogenesis? His life story does not give us a clue, however, we have a hypothesis: in 1926, the Viennese biologist and zoologist, Paul Kammerer, who conducted extensive research with the midwife toad with the intent to demonstrate the inheritance of acquired traits, one of Lamarck's fundamental ideas, had been accused of fraud and degraded by the neo-Darwinian "scientific community." Outraged by the accusation and being sure of his honesty, Kammerer commits suicide. Would Piaget not want to pay tribute to the biologist, and as he a zoologist, in order to restore his image by conducting research similar to his own with the Limnaea Stagnalis and confirming his findings? The fact of the matter is that Piaget conducted an investigation which started in 1927 and lasted 37 years, with all the refinements of the scientific method. Because the waters of the small pond of Lago in which he conducted it had dried up, he had to interrupt it before detailing his ultimate evidence. ${ }^{18}$

This research is especially significant because it was carried out at the same time that Piaget was studying the behavior of his children. Hence the idea of ontogenetic epigenesis that, according to himself, would repeat phylogenetic epigenesis, explained in detail in his work Adaptation vitale et Psychologie de l'intelligence. ${ }^{19}$

This experiment of Jordillon that lasted 37 years is totally ignored by almost all Piaget's scholars worldwide. Notwithstanding, it was thanks to Jordillon's experiment that Piaget was able to create his Theory of Knowledge. This theory

18. Piaget, "Les Races Lacustres de la "Limnaea Stagnalis" - Recherches sur les Rapports de l'adaptation héréditaire avec le milieu," Bulletin Biologique de la France et de la Belgique 63, no. 3 (1929): 424-455; Piaget, "Notes sur des Limnea Stagnalis L. var. lacustris Stud: Elevées dans une Mare du Plateau Vaudois," Revue Suisse de Zoologie 72, no. 38 (1965a): 769-787.

19. Piaget, Adaptation Vitale et Psychologie de l'intelligence. Sélection Organique et Phénocopie (Paris: Hermann, 1974). 
shows the intertwining of the zoologist/biologist with the philosopher. It was the exhaustive observation of many generations of the Limnaea that allowed the Piaget-philosopher to capture the relationship between phylogenesis and ontogenesis of the living organism. It was this experience that showed to the epistemologist, the analogy between the construction of a mollusk's organism and that of the human organism and Reason. It was this experience that explained the contradiction between epigenesis and chance and so that, made possible the creation of a tertium between Lamark and Darwin.

It is absolutely necessary to state that in this article we will not be discussing the concept of epigenesis at the present moment, past or future. Here we will simply adopt Waddington's concept, as understood by Piaget.

The final data of this research conducted with the limnaea stagnalis, from 1927 to 1965 with 80,000 individuals, was published in the 1965 Report. The first of which had come to light in 1929 and already told the accomplishment of a youth dream, to verify the existence of random mutations, an idea that seemed to contradict everything that he himself had observed since the age of 8 with the malacologist Paul Godet and more, to verify the possibility of the transmission of the acquired characters, an issue that had fascinated him since very early on, as he tells on page 454 of the 1929 Report.

Fifteen years after the beginning of this research, Piaget is already sure that there is an epigenesis in the sense of Aristotle - the creator of the concept - as a continuation of a genesis beyond birth..$^{20}$

Two years after the final report of his long and prodigious research, Piaget publishes Biologie et Connaissance, ${ }^{21}$ a work in which he exposes an ontogenetic epigenesis of necessary and universal knowledge, inspired by everything that was observed for 37 years among the Limnaea Stagnalis, now he presents the Principle of epigenetic development as a condition for the acquisition of Knowledge by the human being.

Some could ask how the leap from the epigenesis observed in the context of snails in the Swiss lakes to the Theory of Knowledge took place. Certainly this understanding can only arise from becoming aware of the meaning of Piaget's research with Limnaea Stagnallis, in his own words:22

"Everyone knows that the Lymnaea Stagnalis are bred in the Swiss Great Lakes and in Scandinavia, and that they are a lacustris variety, whose globular shape seems to be linked to water turbulence. In places exposed to waves and on a rocky terrain, every wave causes the animal to adhere to the ground; hence during its growth there

20. Aristotle, On Generation and Corruption (trans.) Arthur Platt (London: Clarendon, 1910), 24.

21. Piaget, Biologie et Connaissance. Essai sur les Relations entre les Régulations Organiques et les Processus Cognitifs (Paris: Gallimard, 1967).

22. Piaget, "Les Races Lacustres de la "Limnaea Stagnalis" - Recherches sur les Rapports de l'adaptation héréditaire avec le milieu," 1929. 
is an increase in the opening of its shell and an effort on the animal muscle, which tends to make its spiral smaller, i. e., it contracts."

In 1929, Piaget had confirmed such statement with a statistical analysis of these variations due to water turbulence, in nature itself, through the environmental changes in the course of the limnaea's growth.

Piaget states: ${ }^{23}$

"We especially sought to demonstrate that the globular shapes found in the most exposed places of the Neuchâtel and Boden Lakes corresponded to a contracted breed which lived long in aquariums and we named them breed V. A less contracted breed (IV) lives in the same lakes and also in the Leman Lake, besides breeds III, II, and I with greater elongations and that are found in calm waters."

"This fact raises an interesting question as to whether breed V is constituted independently of any influence of the environment, according to the interpretation of classic "mutationists", (the ones who carried on the work of De Vries) about 30 or 40 years ago, why does it not take place elsewhere? (except in turbulent waters?) Nothing would prevent them from keeping their contraction in calm waters where I had transported them. He had collected Limnaea from various places in the Swiss lakes and transported them to an aquarium where they lived for generations)."

Since he started to make his catalogues, says he, he has never observed anything other than the maintenance of the contracted spiral. It was at that time that Guyènot told him, says Piaget: ${ }^{24}$

"It is not out of the question that mutations for the "contracted" (limnaea) to appear in various places at random, unrelated to the environment, but for unknown reasons such as oxygen insufficiency, or a harmful effect of the humic acid, they are removed from the calm waters and do not prevail except in the great lakes and more precisely in turbulent waters."

"A first point to examine is the relationship between the individuals that were reared in the pond in Jordillon and those that were reared in aquariums. Let us remember that in the latter, the individuals reared in the aquarium, breed $\mathrm{V}$, came from a scattered population around the Port of Hauterive (Lake Neuchâtel).

Thus, he verified the essential fact that the population bred in the Jordillon and multiplied there for 15 years had not lost any of the contractions as those of its predecessors in aquariums. In contrast, they presented a sharper contraction, inbetween the preceding one and that of the parent population living in the lake (...) If the Jordillon population is a little more contracted than that of Lake Hauterive, it is naturally because in that parent station there is a certain phenotypic contraction due to the waves, which could be added to the genotypic contraction, whereas the calm waters of the Jordillon ignore that factor.

23. Ibid, 769.

24. Ibid, 770. 
(..)

The genotype is simply what is common to all phenotypes of the same breed, and if we know that there is a breed V, it follows that in "pure" lineages and in identical conditions (aquariums of the same shapes and dimensions) it differs from breed I to IV.

$(\ldots)$

After the Jordillon experiment it seems to us, therefore, even more difficult than before to explain (these facts) without resorting to the influence of the environment as breed V is produced only in turbulent places of the Great Lakes since it also could live anywhere. (...)"

At the same time that Piaget demonstrates - over the course of 37 years - the influence of the environment in the Limnaea Stagnallis organism and describes its epigenesis entirely in accordance with what Waddington (1957) 25 says, it makes the very concept of chance untenable. According to him: ${ }^{26}$

“This tells us that the problem data raised by our Lymnaea are as follows:

1) The phenotypic contraction is easily accounted for in nature by a kinetogenesis on the basis of the agitation versus substrate complex.

2) In lacustrine stations where this phenotypic contraction is maximum and only in them do we find a genotype (breed V) oriented in the same direction.

3) This hereditary modification could take place anywhere since nothing prevents a contracted form from living in calm waters, but nowhere did we find such event. From the probabilistic point of view, could we then admit that the appearance of contracted genotypes occurs by chance only at the points where a maximum phenotypic contraction results from water agitation by kinetogenesis or is there a causal link between these phenotypic and genotypic contractions?

Here is a special case of countless situations in which an initially non-hereditary variation then seems to settle. However, what is interesting about this special case is that it all seems to happen in a merely mechanical domain as that of animal movements in the course of its growth, and the repercussions of this motricity on the shape of the animal; the apparent effect of the environment on the hereditary form simply impacts the most.

In our 1929 article we were hoping for the advent of a theoretical position that could constitute a "tertium" among the ideas of Lamarck, who explained it all by means of the environment, but not verifying it experimentally, and the classical mutationism of which he only had notions about random atomistic variations unrelated to the

25. C. H. Waddington, The Strategy of the Genes (London: George Allen \& Unwin Ltd, 1957).

26. Piaget, "Les Races Lacustres de la "Limnaea Stagnalis" - Recherches sur les Rapports de l'adaptation héréditaire avec le milieu," 1929, 771-778. 
environment and their selection subsequent to the event, due to the death or survival of the organisms bearing such variations. Now it seems that we are in the process of reaching a compromising position today (1965) due to population genetics and Waddington's impacting work (1957). Situating our problem in such perspectives may prove to be interesting.

\section{(...)}

The genomes are systems with different forms of balances, imbalances and rebalancing of unfavorable mutations (cf. classical experiment by Dobzhansky and Spasski).

(...)

Above all, as Waddington insisted, selection does not occur in the genes directly, but rather exclusively in phenotypes as an interaction between the genome and the environment. From such a point of view, selection is a choice of the most "capable of responding to the environment."

\section{$(\ldots)$}

Selection, therefore, constitutes a modification of genetic equilibrium proceeding in a manner comparable to those in which the action of an external factor on the organism was previously conceived, but substituting the simple causal action for a probabilistic action on the proportions of a multi-unit. In other words, the character that is joined or removed is no longer conceived as an expression of a disjunction or an absolute withdrawal, but as a result of a change of proportions in an organized system. That is why we do not speak of a new mutation anymore, but of a new rebalancing that modifies the genetic system in its entirety. (In fact, it is necessary to reverse the possible emergence or discovery of new genes since their number varies according to groups)."

Piaget summarizes his goal in his lasting research as follows: ${ }^{27}$

"The aim of this transposition experiment was to show that the contracted genotype of the Limnaea Stagnalis, which were constituted only in the most exposed places to the waves of the Neuchâtel and Constance Lakes, could survive in calm waters and preserve their contraction "character". Thus, the following hypothesis falls apart: that such genotypes of breed V could appear anywhere at random, but they would be eliminated in the "marais" or in the small lagoons for several reasons excluding their survival in such environments."

Piaget states that, "without referring to the acquired characters in the Lamarckian sense (transmission already in the first generation and without giving much value to endogenous reorganization), ${ }^{28}$ or the recent studies (1960) of the action of the RNA on the DNA," sought to interpret the phenomena he observed with breed $\mathrm{V}$, which

27. Ibid, 779 .

28. Piaget, Biologie et Connaissance. Essai sur les Relations entre les Régulations Organiques et les Processus Cognitifs, 1967, 128-131. 
advocate in favor of the existence of hereditary variations that followed the phenotypes which resulted from the influence of the environment; and that later on the same breed may well live in calm waters preserving their characters, as a phenocopy (phénocopie) (or copy of the phenotype by the genotype). We must now clarify that we shall be discussing the term phenocopy later on, which is not entirely in accordance with Piaget's explanations, for all through the explanations he provides us, he states that it is not exactly a "copy" of the phenotype. He must have used this term for lack of a more suitable one within the French language. We shall propose a neologism that could express perfectly well, in English, what Piaget meant concerning the phenotype and its relationship to the genotype: pheno-endogenous requirements, instead of phenocopy, i.e., endogenous requirements of the phenotype. Immediately after using that word which indicates a concept, Piaget continues the report, explaining that: ${ }^{29}$

“(...) if the environment engenders a common phenotype, there is no reason for endogenous reconstruction, on the contrary; if the exogenous variation is the source of a more or less profound imbalance, it can affect the regulatory genes corresponding to the modified regions of the organism. There is, then, a repercussion of the imbalance thus created, indicating through a feedback the existence of a disturbance in the syntheses commanded by the genome (...) In this specific case where the phenotype has disturbed the balance of the internal environment; it is the latter that will constitute the selection instruments: there will then be an "organic selection" in Baldwin's sense and it is then normal for the endogenous variation to end up resembling the phenotype, since it was forced by internal selections to mold itself in the framework modified by the phenotype. In most cases, phenotypes are closely linked to behavior, and in the case of plants, to so-called reactive variations, the transition from exogenous to endogenous thus appears to constitute a general process that occurs in all domains of life."

Here a reference to his research with alpine cypresses which, due to having their seeds transplanted from low altitudes to high altitudes, had the length and width of their leaves changed in the generations following the initially altered phenotype.

In these two cases observed by Piaget, he understands that the phenotypic variation shows a result that reveals not only a threat to the environment, but also a process in which the organism tends to "expand its environment and increase its powers; and in both cases, the final genotype achieves a balance the phenotype only sought." 30

In this same work of 1974, Piaget upon narrating his research already published in the Report we mentioned above on the Limnaea, along with the

29. Piaget, Adaptation Vitale et Psychologie de l'Intelligence. Sélection Organique et Phénocopie, 1974, 44-45.

30. Ibid, 37. 
research he had already conducted with humans until 1965, and reported in: The Origin of Intelligence in Children, ${ }^{31}$ The Construction of Reality in the Child, ${ }^{32}$ The formation of the Symbol in the chil;33 (in addition to another twenty or thirty studies with children that followed until the publication of the Report transcribed here), he comments: ${ }^{34}$

"So, how can we not be surprise with the convergence between this biological law that seems general and the work of the forms, even the higher forms of intelligence, whose new constructions rest on information taken not from objects as such, but from actions or the coordination of actions that the subject exerts over objects, which is not the same thing at all, as we will insist later on (...)."

So the elaboration of such operating structures on this cognitive terrain has its onset with actions that are internalized as operations, but performed by mental structures with their capacity to represent, and it is preceded by trials and errors of an empirical nature, as if these corresponded to the initial phenotypic responses and to the operations as the functioning of specific organic mental structures for the act of knowing, such as endogenous, genotypic responses.

In the case of a purely biological, "phenocopy", it is then about a change in the phenotype that can lead to a modification in the genome, which could be explained for genome's reorganization in response to the inputs of the phenotype. As far as intelligence is concerned, the term "endogenous" must be understood as a set of organic structures that are formed from within child operations in the environment.

Let us synthesize this process that Piaget and Waddington, ${ }^{35}$ will call Ontogenetic Epigenesis. This process begins with the empirical experience, with the actions of a human being upon the environment aimed to understand the world. Knowledge of the physical world begin with the establishment of relations between material objects, never at random, but always displaying the logic described by Piaget when he studied the children of the Binet \& Simon Laboratory, and who were later observed again in several parts of the world by his research assistants, including the members of our Laboratory at USP (University of São Paulo). All these observable logical relations can be called phenotypic and remain unconscious up to 5-6 years of age, so that becoming conscious and verbalized, but still limited to actions with material objects.

31. Piaget, La Naissance de l'Intelligence chez l'Enfant (Paris: Delachaux \& Niestlé, 1936).

32. Piaget, La Construction du Réel chez l'Enfant (Paris: Delachaux \& Niestlé, 1937).

33. Piaget, La Formation du Symbole chez l'Enfant (Paris: Delachaux \& Niestlé, 1945).

34. Piaget, Adaptation Vitale et Psychologie de l'Intelligence. Sélection Organique et Phénocopie, 1974, 39.

35. Waddington, The Strategy of the Genes, 1957; Waddington, Towards a Theoretical Biology (Edinburgh, Scotland: Edinburgh University Press, 1968); Waddington, The Evolution of an Evolutionist (Edinburgh, Scotland: Edinburg University Press, 1975). 
The paramount fact is that these logical relationships are insensibly passed into children's consciousness and on to their speech in a way that they're introjected and represented by the image-making faculty, so that humans can think about them. Piaget understands this movement as an "abstraction reflechissante" (that means something that is reflected as an image at a higher level than that of actions that will allow for the rise of deduction). Once aware of these logical relationships, it can be said that children reached the concrete-operational stage, that is, they already know how to operate even if only on objects. This stage will be demonstrated by the formal model of groupings that will precede the coming of human Reason into the structure of the Abelian Group. This stage is explained by the formal model of the INRC Group, in Piaget's theory.

What is the relevance of this coming to the so defined "operational stage", in Piaget's Theory? This new capacity means that new organic mental structures specific to the act of knowing have been completed in the organism, and will also determine progress in adaptation. This new equilibrium level is transient because it simultaneously means brain progress that increases the capacity of the individual to perceive new stimuli in the environment, and new relations to be established therein, in a dialectic process: organism vs. environment, which will cause new imbalances and rebalances. The endogenous, organic construction of mental structures here constitutes the genotype which we referred to in the purely organic phenocopy, since the phenotypic information of the logic underlying the actions in empirical experience passes through reflexive abstractions causing the evolution of the functioning of the mental structures, consisting in the establishment of logical relations, performed in empirical experience, but that shall evolve into logical and mathematical relations independent of material objects, according to Jean Piaget. Thus we could observe Maria Gabriella, age 9, verbalizing the following reasoning: (...) "if there is only 'yes' and 'no', if I say no to 'no' I'm saying yes." (...) the "double negation" occurred to Gabriella spontaneously, it is as if we were watching live the moment of arrival at abstract thinking.

The fact that the relations of Classical Logic appear to underlie the behavior of all human beings, since not even a single case among children living in a society has falsified such observation, leads Piaget to hypothesize that the very functioning of the brain occurs according to Classical Logic. In his own words, Piaget says: ${ }^{36}$

"In conclusion, the mental activities whose progressive structuring prepares the logical structures thus cover the entire development field (or ontogenetic evolution), which means that logic has its roots situated in a much deeper level than commonly imagined. In pursuing them, we are forced to go back so far that we may ask ourselves whether the integrations proper to the nervous mechanisms are not

36. Piaget, "Les Activités Mentales en Rapport avec les Expressions Symboliques Logique et Mathématiques," Synthese 9, no. 2 (1954): 144-145. 
already an outline of logical fittings." (...) This leads us to assume that the evolutionary process, which we have referred to, is isomorphic to an organic evolution."

The originality of Piaget's hypothesis ${ }^{37}$ is to assume the Classical Logic as an expression of organic brain functioning. Classical Logic, for since Aristotle who created Logic by observing the arguments of those who discussed in the public Square, up to George Boole ${ }^{38}$ it was understood as a set of laws of thought. Subsequently, Logic will be understood, in general, just as a language.

Piaget adds that when looking at contemporary cybernetic models, related to brain activity, appeal to equilibrium processes using the mathematical structures of network and groups, there are indications (or would it be an illusion?) that the evolutionary process of Reason or logical mathematical intelligence in ontogenesis is concurrent with the organic evolution of specific mental structures for the act of knowing.

In fact, in the $21^{\text {st }}$ century, we have had important articles on this subject that justly address the Piagetian theory. ${ }^{39}$

In Piaget's article Biologie et Connaissance, ${ }^{40}$ a summary of the book with the same title he was writing and later published in 1967, Piaget says a great many interesting things about his fundamental concern that, for example, when aiming to compare knowledge mechanisms to those of life, he finds that the former ones prolong and use the organic self-regulations from which they derive. Piaget shows us that if his multiple analyses lead him to highlight the continuity that links organic life and cognitive mechanisms, they must also show that they are differentiated and specialized organs of physiological regulations in their interactions with the environment, that is, when prolonging organic structures have special functions, even if they are still biological, until reaching the level of logical and mathematical production, the result of brain functioning, which is organic, but capable of generating purely abstract knowledge; for Piaget physiology ends where logical - mathematical relations begins.

37. Piaget, "Logique Formelle et Psichologie Génétique," In Les Modèles et la Formalization du Comportement. Paris: Editions du CNRS, 1967, 277; Piaget, "Le Problème Neurologique de l'Interiorisation des Actionsen Opérations Réversibles," 1949.

38. Apud C. Mangione and S. Bozzi, Storia della Logica. Da Boole ai Nostri Giorni (Roma: Garzanti Editore, 1993).

39. Such as: 1) E. E. Aksoy, M. Schoeler and F. Wörgötter, “Testing Piaget's Ideas on Robots: Assimilation and Accommodation using the Semantics of Actions," in Development and Learning and Epigenetic Robotics (ICDL-Epirob), Joint IEEE International Conferences 2014, 107-108; 2) S. T. Parker, J. Langer and C. Milbrath (Eds.), Biology and Knowledge Revisited: From Neurogenesis to Psychogenesis (Psychology Press, 2014); 3) S. Campanella, "Understanding Bio-Cognitive Change: Jean Piaget and the Path to Epigenetic Innovation," Journal Paradigm 1 (2019): 7-22.

40. Piaget, "Biologie et Connaissance," Diogène, no. 54 (1966): 4. 
In this article, exactly between the end of his research with the Limnaea Stagnalis and the preparation of his theory of knowledge exposed in Biologie et Connaissance, Piaget seeks to fill a certain gap that could exist between the study of "phenocopy" in phylogenesis and ontogenesis. Actually, what is the link that would link his research with the Limnaea Stagnalis and children, the human offspring? Right, he reveals to us the isomorphisms between phylogenesis and ontogenesis, but how can we explain the emergence of the conscious logical and mathematical functioning in humans?

The text that prepares us for the book Biologie et Connaisance shows us this link.

Piaget says that starting from Ethology's elementary data, animal knowledge is of the "savoir faire" order, or of the useful and practical know-how; instinct essentially consists of nourishment, protection against the enemy and reproduction, added to the different modes of social organization in the sense of survival of the species and the individual. Perceptual or sensorimotor types of learning do not emerge from a functional framework and the same is true of a large part of practical or sensorimotor intelligence.

.Mammals, we know, distance themselves a little bit from other animals and have their environment expanded by the act of playing and even by actions that can no longer be interpreted as part of the instinct, as demonstrations of "gratitude" towards caregivers. We have notable cases observed with these animals: the cow that licks for more than half an hour its caregiver who, by assisting her in giving birth, saved her life and that of her calf. Our pet Poupée, who whenever someone in the family he belonged felt ill, spent the day at the foot of his bed. The kitten Milly which, when watching her owner on the lap top, imitated him by tapping his paws on the keyboard ... We know the scientific experiments with chimpanzees in which they created new tools in order to reach food, etc., but all this shows us an extension of the environment, which had already been observed among snails or Limnaea Stagnallis.

Human beings expand their environment much more rapidly, but their cognitive processes therein involved go through the expansion of their universe, such as discoveries of other lands, maritime discovery, other continents, and exploration of the universe. What do Physics and Chemistry do other than build knowledge that always goes in this direction of expanding our environment, our universe? It can be said that knowing is expanding the world of the subject who acts, always on the basis of their possibilities, programmed at first but then undergoes changes in function of exchanges with the environment and transmission of new knowledge to their descendants.

Piaget proposes as the very cause of knowledge, suitable for both phylogenesis and ontogenesis and the link between both of them: knowing the world around us and thus expand it more and more.

Were does de difference between knowledge in the others animals and the human whose achievements are unmatched begins? Piaget replies: In éclatement 
de 1'instinct, ${ }^{41}$ that is the out break of instinct; in the almost complete disappearance, among anthropoids and human beings of a totally organic form to knowing that now extends into new forms of regulation that when overcoming the previous one, do not take their place, but instead preserve it by dividing its components in two complementary directions.

With the outbreak of the instinct, the hereditary programming of the form of knowing disappears and is replaced by cognitive, flexible and built selfregulations.

The fact that knowledge based on ontogenesis begins at such an early moment made the theoreticians of logical-mathematical knowledge not even think of looking for its origin in biological functioning, "at least, not before the relationship between the logic of the models was shown by Mc Culloch $\mathcal{E}$ Pitts $^{42}$ and the logic of neurons," says Piaget. ${ }^{43}$

Piaget states in addition:

"There is no exaggeration or metaphor in saying that the nervous reaction ensures the continuous transition between physiological assimilation in the broad sense and cognitive assimilation in the sensory-motor form. At all levels, logic inference is thus at the center of cognitive processes long before the development of general and stable operating structures." 44

\section{How did Piaget himself try to demonstrate his Biological Theory of Knowledge?}

Piaget and Grize ${ }^{45}$ thought that if it was possible to formally prove that there is an intermediate form of thinking to reason between non-logical thinking and human logical thinking; this would be the demonstration of Epigenetic Ontogenesis. It would not be "proved" through actions (with observational facts), but through formal logic.

Afterwards they demonstrated the existence of an intermediate moment between those sufficiently known moments in the ontogenesis of logicalmathematical thinking: $1^{\text {st }}$ ) that of a total absence of logic in the individual's consciousness, (from birth and continuing in the first years of life, in which a logic underlying the actions is gradually being outlined, but not at the level of

41. Ibid, 23; Piaget, Biologie et Connaissance. Essai sur les Relations entre les Régulations Organiques et les Processus Cognitifs, 1967, 410.

42. W. Mc Culloch and W. Pitts, "A Logical Calculus of the Ideas Immanent in Neurons Activity," Bulletin of Mathematical Biophysics 7 (1943): 115-133.

43. Piaget, "Biologie et Connaissance," 1966, 25; Piaget, Biologie et Connaissance. Essai sur les Relations entre les Régulations Organiques et les Processus Cognitifs, 1967, 256-257.

44. Ibid, 256.

45. Piaget and J. B. Grize, Essai de Logique Opératoire, 2nd Edition (Paris: Dunod, 1972). 
consciousness); $2^{\text {nd }}$ ) that of the ability to understand abstract relationships that correspond to the structure of the Abelian group in mathematics.

The great merit of Piaget's Theory of Knowledge was to discover the existence of an intermediate moment between the ones above mentioned, previously unknown to both mathematicians and epistemologists in general, not to mention those dedicated to biological knowledge, including neurologists.

The ability hitherto not perceived by scholars, for the child to be aware of a logic carried out with objects in a concrete world and which corresponds to that an imperfect Group, underlying its actions and its discourse, is necessarily a precursor of the Abelian Group; the logical relationships made aware by the human newborn are, as show by Piaget, in this stage, of its evolution, still always linked to the concrete world, that is, to its actions. Hence the name given to intermediate moment that he discovered and that would constitute the very possibilities of the human brain, from the Period of Concrete Logic, expressed $n$ the model he called Groupement, (Grouping) almost a Abelian Group, ("Groupe"), but not yet, it lacks some abstract relationships in the process of being acquired in the next moment and not by all human beings...

Grouping is then an incomplete mathematical structure that reveals and formalizes the reasoning of the average 7/10 year old children. The laws expressed in the model designated as Grouping are: composition, reversibility, associativity, and identical operation (which includes tautologies). Epigenetic ontogenesis will lead human beings to the possibilities of reasoning expressed in the model named the INRC Group (Identity relations, N Inversion, Reciprocity, and Correlative operations). These would be the essential possibilities of propositional operations, thus allowing the subject to think through hypotheses, verifying or falsifying them. That moment, states Piaget, when human beings become capable of thinking according to all the possibilities of the Abelian Group would signal the end of the physiological construction of the human brain. ${ }^{46}$ This construction would be ready and the reasoning thereof would no longer be only a result of an organic functioning, but an abstract consequence, result of this very functioning. ${ }^{47}$ Thus, henceforth, human beings would be able to create new things and understand complex systems in the different areas of Mathematical Logic, Philosophy etc.

Here Piaget finds equivalent to a purely organic phenocopy, a cognitive phenocopy in which the operations determined by the functioning of mental strctures imitate, copy, initially phenotype behaviors, requested by the pressure of the environment. Piaget explains that in phenocopy whose true meaning would be pheno-endogenous requirements, the actions with the objects or the facts of

46. Ramozzi-Chiarottino, Modèle et Structure chez Piaget (Genève: Archives Jean Piaget: S.I.V., 1972). 41.

47. Piaget, "Essai sur la Nécessité," Archives de Psychologie XLV (1977). Université de Génève, 245. 
the environment, affect the endogenous processes with repercussions on those that are under construction causing them to evolve

Cognitive phenocopy begins with the construction of mental structures while there is a direct relationship between the human subject that strives to know and the physical environment. However, at some point in the dialectical process, by virtue of which the construction of Reason takes place, the exchange between the organism and the environment is no longer restricted to physical objects as such, but involves concepts. These concepts already correspond to the abstract product of brain functioning; they derive from reasoning, from the ability to develop relationships and stablish logical relations, both products of organic functioning, and generated by it. Whether it is about biological or cognitive phenocopies, or reflective abstraction, as previously explained, says Piaget, we find the same mechanism again; a rebalancing by endogenous reconstruction and then its overcoming but with preservation (an aufhebung), thanks to a reorganization with new combinations, but whose elements are harvested from the previous system. ${ }^{48}$

\section{Conclusion}

It is possible for human beings to achieve the necessary and universal Knowledge, thanks to the exchanges that their organism develops with the environment that give rise to the epigenetic ontogenesis of their specific organic mental structures for the act of knowing.

\section{Bibliography}

Adam, C. and P. Tannery. Oeuvres de Descartes. [Descarte's Works.] Paris: Vrin, 1969/1996. Aksoy, E. E., M. Schoeler and F. Wörgötter. "Testing Piaget's Ideas on Robots: Assimilation and Accommodation using the Semantics of Actions." In Development and Learning and Epigenetic Robotics (ICDL-Epirob), Joint IEEE International Conferences 2014, 107-108.

Aristotle. On Generation and Corruption. Translated by Arthur Platt. London: Clarendon, 1910.

Campanella, S. "Understanding Bio-Cognitive Change: Jean Piaget and the Path to Epigenetic Innovation." Journal Paradigm 1 (2019): 7-22.

Cassirer E. El Problema del Conocimiento, de la Muerte de Hegel a Nuestros Dias. [The Problem of Knowledge, from Hegel to Present Days). Mexico, Buenos Aires: Fondo Del Cultura, 1948.

Cellerier, G. Piaget. Paris: PUF, 1978.

Eisler, R. Kant-Lexikon. [Kant's Lexicon.] Paris : Èditions Gallimard, 1994.

48. Piaget, "La Logistique Axiomatique ou "Pure", la Logistique Opératoire ou Psychologique et les Réalités Auxquelles elles Correspondent," Methodos: Rivista Trimestrali di Metodologia e di Analisi del Linguaggio 4, no. 13 (1952): 72-84. 
Granger, G. G. La Vérification. [The Verification.] Paris, Odile Jacob, 1992.

Heisenberg, W. La Nature dans la Physique Contemporaine. [The Nature Representation in Contemporary Physics.] Paris: Gallimard, 1962.

Kant, I. Critique de la Raison Pure. [Critique of Pure Reason.] Paris: PUF, 1781/1950.

Mangione C. and S. Bozzi. Storia della Logica. Da Boole ai Nostril Giorni. [History of Logic. From Boole to our Days.] Roma: Garzanti Editore, 1993.

Mc Culloch, W. and W. Pitts. "A Logical Calculus of the Ideas Immanent in Neurons Activity." Bulletin of Mathematical Biophysics 7 (1943): 115-133.

Parker, S. T., J. Langer and C. Milbrath (Eds.) Biology and Knowledge Revisited: From Neurogenesis to Psychogenesis. Psychology Press, 2014.

Piaget, J. Recherche. [Research.] Lausanne: La Concorde, 1918.

Piaget, J. "Les Races Lacustres de la "Limnaea Stagnalis" - Recherches sur les Rapports de l'adaptation héréditaire avec le milieu." [The Lake Species of the "Limnaea Stagnalis"

- Research on the Relationship between Heredity Adaptation and the Enviroment.] Bulletin Biologique de la France et de la Belgique 63, no. 3 (1929): 424-455.

Piaget, J. La Naissance de l'Intelligence chez l'Enfant. [The Oringis of Intelligence in Children.] Paris: Delachaux \& Niestlé, 1936.

Piaget, J. La Construction du Réel chez l'Enfant. [The Construction of the Reality in the Child.] Paris: Delachaux \& Niestlé, 1937.

Piaget, J. La Formation du Symbole chez l'Enfant. [Symbol Formation in the Child: Imitation, Play and Dream, Image and Representation.] Paris: Delachaux \& Niestlé, 1945.

Piaget, J. "Le Problème Neurologique de l'Interiorisation des Actions en Opérations Réversibles." [The Neurological Problem of Interiorization of Actions in Reversibles Operations.] Archives de Psychologie 32, no. 128 (1949).

Piaget, J. "La Logistique Axiomatique ou "Pure", la Logistique Opératoire ou Psychologique et les Réalités Auxquelles elles Correspondent." [The Axiomatic Logistics or "Pure", Operational Logistics or Psychology and the Realities to which they Correspond.] Methodos: Rivista Trimestrali di Metodologia e di Analisi del Linguaggio 4, no. 13 (1952): 72-84.

Piaget, J. “Les Activités Mentales en Rapport avec les Expressions Symboliques Logiques et Mathématiques." [Mental Activities in Relation to Symbolic, Logical and Mathematical Expressions.] Synthese 9, no. 2 (1954): 144-CLA II.

Piaget, J. "Les Modèles Abstraits sont-il Opposés aux Interprétations Psychophysiologiques dans l'Explication en Psychologie?" [Are the Abstract Models Opposed to the Psycho-Physiological Interpretations in Psychological Interpretation?] Revue Suisse de Psychologie pure et appliquée XIX, no. 1 (1960).

Piaget, J. “Notes sur des Limnea Stagnalis L. var. lacustris Stud: Elevées dans une Mare du Plateau Vaudois." [Notes on the Limnaea Stagnallis L. Var. Lacustris Stud Raised in a Pond of Vaudois Plateau.] Revue Suisse de Zoologie 72, no. 38 (1965a): 769-787.

Piaget, J. Sagesse et Illusions de la Philosophie. [Wisdom and Illusions of Philosophy.] Paris, $1965 b$.

Piaget, J. “Biologie et Connaissance.” [Biology and Knowledge.] Diogène, no. 54 (1966): 3-26.

Piaget, J. Biologie et Connaissance. Essai sur les Relations entre les Régulations Organiques et les Processus Cognitifs. [Biology and Knowledge: An Essay about the Relations between Organic Relations and Cognitive Processes.] Paris: Gallimard, 1967. 
Piaget, J. "Logique Formelle et Psichologie Génétique." [Formal Logic and Genetic Psychology.] In Les Modèles et la Formalization du Comportement. Paris: Editions du CNRS, 1967.

Piaget, J. and J. B. Grize. Essai de Logique Opératoire. [Essay by the Operative Logic.] 2nd Edition. Paris: Dunod, 1972.

Piaget, J. Adaptation Vitale et Psychologie de l'intelligence. Sélection Organique et Phénocopie. [Vital Adaptation ad Psychology of Intelligence. Organic Selection and Phenocopy.] Paris: Hermann, 1974.

Piaget, J. "Essai sur la Nécessité." [An Essay on the Necessary Knowledge.] Archives de Psychologie XLV (1977). Université de Génève.

Plato. Dialogues. Translated by Émile Chambry. Paris: Garnier- Flamarion, 1969.

Ramozzi-Chiarottino, Z. Modèle et Structure chez Piaget. [Model and Structure in the Piaget's Work.] Genève: Archives Jean Piaget: S.I.V., 1972.

Ramozzi-Chiarottino, Z., G. Franck-Cunha, J.-J. Freire and A. A. Ferraz. Jean Piaget's Unrecogized Epigenetic Ontogenesis of the Logical-Mathematical Thought. Athens: Atiner's Conference Paper Series, 2017.

Trindade dos Santos, J. Fragmentos do Poema de Parmênides. [Parmenides Poem Fragments.] Lisboa: Gulbekian, 1997.

Waddington, C. H. The Strategy of the Genes. London: George Allen \& Unwin Ltd, 1957.

Waddington, C. H. Towards a Theoretical Biology, Edinburgh, Scotland: Edinburgh University Press, 1968.

Waddington, C. H. The Evolution of an Evolutionist. Edinburgh, Scotland: Edinburg University Press, 1975. 